\title{
Ócio e cinema na fotografia de Marc Ferrez
}

\author{
Mauricio Lissovsky' \\ https://orcid.org/0000-0002-0734-790X \\ I - UFRJ \\ Rio de Janeiro (RJ), Brasil
}

Resumo: Os autocromos estereoscópicos que Marc Ferrez (1843-1923) produziu em sua última década de vida são radicalmente diferentes da obra conhecida do autor. Este ensaio retoma os panoramas urbanos do Rio de Janeiro na virada do século e sugere, em contraste com esses, que as imagens idílico-melancólicas realizadas, em sua maioria, na Europa, durante o período da Grande Guerra, são resultado da influência do cinema no olhar do veterano fotógrafo.

Palavras-chave: fotografia brasileira; autocromos; estereoscopia; fotograma.

Abstract: Iddle life and cinema in Marc Ferrez' photography - The stereoscopic autochromes that Marc Ferrez (1843-1923) made in his last decade of life are radically different from the author's most known work. This essay discusses initially a few urban views of Rio de Janeiro around 1900 and suggests, in contrast with them, that the idyllic-melancholic images produced, mostly in Europe, during the Great War period, are the result of the influence of cinema on the gaze of the veteran photographer.

Keywords: brazilian photography; autochromes; stereoscopic views; photogram.

\section{Introdução}

A recente exposição "Marc Ferrez, território e imagem" (IMS, Rio de Janeiro, 07/12/2019 a 15/03/2020) e a cronologia de sua vida e obra, estabelecida por Ileana Pradilla (2019), são um incentivo a reler e repensar o trabalho deste que foi, seguramente, nosso mais significativo fotógrafo paisagista do século XIX - responsável, entre outras coisas, pela difusão, no Brasil e no exterior, do perfil do Rio de Janeiro. Entre os materiais que mais chamaram a atenção na exposição, por terem sido pouco exibidos ou publicados menos ainda em seu conjunto -, estão os autocromos estereoscópicos que Marc Ferrez (1843-1923) realizou em sua última década de vida. As imagens idílico-melancólicas, europeias em sua maioria, são radicalmente diferentes daquilo que o veterano fotógrafo 
havia produzido e acumulado em seu arquivo nas décadas anteriores. Este ensaio surgiu da necessidade de compreender essa diferença.

\section{Dois retratos de família}

Consideremos inicialmente duas fotografias domésticas. A primeira é de 1898, realizada no Rio de Janeiro (Figura 1). Vemos os dois filhos do fotógrafo, em trajes de domingo, engajados em sábias e elegantes atividades: a leitura e a observação da natureza. Apesar de simular casualidade, a imagem tem um forte componente alegórico. Na pintura acadêmica, o contraponto à leitura poderia ter sido um cavalete ou, com mais frequência, um piano. ${ }^{1}$ Mas as pinturas, nessa fotografia, já estão concluídas e penduradas. O pai de Ferrez havia chegado ao Brasil em 1817, tendo sido professor da Academia, no Rio de Janeiro. Para a nova geração dos Ferrez, a preparação dos jovens incluía agora manipular dispositivos óticos. Porém, mais do que apenas sugerir a educação dos filhos e o apuro de seus talentos, essa imagem é uma alegoria da formação do próprio fotógrafo: um autorretrato ou, mais precisamente, um tableaux autobiográfico que evoca tanto sua origem como as habilidades e a vocação, não apenas de artista, mas de empresário. O que essa família lê? A mesa dispõe de uma ampla variedade de materiais, além dos tradicionais livros e jornais das poses oitocentistas convencionais: álbuns, livros-caixa, relatórios. Para a vida moderna, a poesia e o romance não seriam suficientes - restringir-se às belas letras seria o mesmo que tentar observar e compreender o mundo a olho nu.

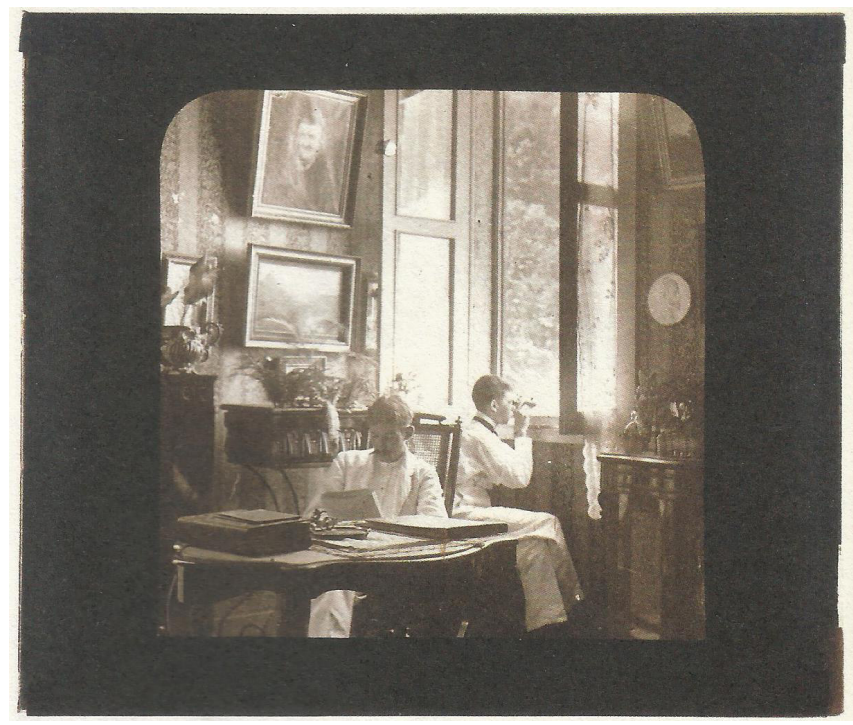

Fig. 1. Os filhos Júlio e Luciano na casa da família Ferrez, no Rio de Janeiro, c. 1898.

1 Veja-se, por exemplo, de Almeida Júnior, "Descanso do modelo" (1882) ou "Cena de família de Antônio Augusto Pinto" (1891). 
Consideremos outra fotografia, feita 14 anos depois, em 1912 (Figura 2). Os personagens foram arranjados de forma tradicional. O contraste dos netos logo chama a atenção, um espantado, um pouco receoso (Eduardo) e outro divertido, fascinado talvez (Gilberto). Alguns objetos da cena anterior ainda estão presentes nas paredes da sala, cobertas de motivos florais, assim como também o filho Júlio. Porém, o que me interessa aqui, em particular, é a postura do velho fotógrafo, que não assume uma pose conservadora e circunspecta, típica dos estúdios oitocentistas, mas inclina-se, como se receasse não aparecer no retrato (ou não aparecer em lugar próprio ou conveniente). Sobretudo e essa foi minha primeira e mais durável impressão -, como se tivesse acabado de chegar e improvisado um lugar para si. Uma segunda suposição: sua inclinação reverbera a postura do menino de cerâmica, ao fundo, que leva um cesto na cabeça, procurando mantê-lo fora do alcance da irmã. Estaria Marc Ferrez, nesse momento, sob a influência mimética de uma escultura? Testemunhamos o efeito no corpo de um vudu fotográfico? A segunda hipótese não é mais difícil de provar que a primeira. De um modo ou de outro, parece-me claro que algo sucedeu entre a fotografia dos filhos de 1898 - a composição alegórica que simula uma cena doméstica - e o retrato familiar no qual se infiltra timidamente um instantâneo - a inclinação do recém-chegado para "caber" na foto (ou, talvez apenas para mim, o efeito mimético suscitado por um boneco de cerâmica). O que pretendo argumentar neste ensaio é que isso que sucedeu ao velho fotógrafo não diz respeito à evolução da técnica fotográfica, mas, primordialmente, à entrada do cinema em sua vida.

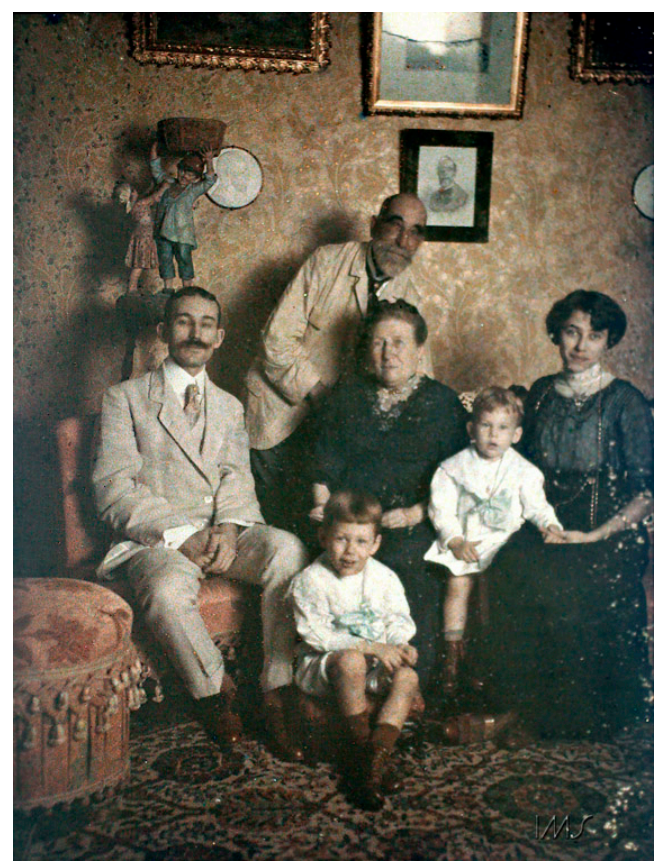

Fig. 2. Marc Ferrez e família. Rio de Janeiro, c. 1912. 
Uma das características dos objetos técnicos, na época de sua invenção, antes de adquirirem um lugar estável na esfera da cultura e uma forma-padrão como mercadoria, é ter uma designação incerta. Assim, isso que chamamos hoje "cinema" recebeu vários nomes. Um deles foi "biógrafo", não porque o aparelho contasse a história de alguém, mas porque restituía a vida, reanimava as fotografias. Da mesma maneira, em vez da alegoria autobiográfica da primeira foto, a segunda introduz um movimento na representação estática das três gerações de Ferrez. As novas mídias não modificam apenas nossa percepção do mundo e as formas como o representamos, mas também nossos gestos e a relação que temos com os próprios corpos.

\section{Percursos fotográficos}

Marc Ferrez começa a vender equipamentos de cinema em sua loja em 1905. Mas não foi apenas o tino comercial do empresário que se deixou afetar por esse novo estado da imagem, o olhar do fotógrafo também foi atravessado por ele. Afinal, a fotografia como espetáculo - lanterna mágica, estereoscopia, grandes álbuns, panoramas, exposições sempre havia Ihe interessado mais que o retratismo miúdo do estúdio burguês. Seus últimos grandes projetos, o álbum das edificações da Avenida Central e sua entrada no ramo do cinema como exibidor (com a inauguração do Pathé, no Rio de Janeiro), são ambos de 1907. ${ }^{2}$ Nesse mesmo ano começa a afastar-se dos negócios da fotografia, em particular do comércio de equipamentos e insumos (PRADILLA, 2019, 118-121).

Percorro distraído as fotografias dos edifícios da Avenida Central quando um perfil do Teatro Municipal interrompe o passeio (Figura 3). Retornei a essa fotografia várias vezes, no decorrer da pesquisa, como se estivesse vendo esse prédio, que conheço desde menino, pela primeira vez. Finalmente me dei conta de que minha surpresa era vê-lo assim, por inteiro e de perfil, sem árvores na calçada ou quaisquer outros elementos que perturbassem a apreensão. O estranhamento decorria de uma obviedade. O Municipal havia sido concebido para ser visto de frente, desde a praça que logo será apelidada Cinelândia, os volumes progredindo em direção ao fundo e antecipando o percurso do visitante: entrada, foyer, escadas, plateia, galerias e camarotes, a grande cortina, o palco. Assim, de perfil (a fotografia exibe a face lateral voltada para a Avenida Central, hoje Rio Branco), achei-o péssimo. O atravessamento de estruturas é brutal, quase isso que os franceses chamam "telescopagem" - um grave acidente automobilístico em que veículos de diferentes formas e tamanhos vão entrando uns por dentro dos outros. O projeto claramente não previa uma promenade em torno do prédio, e o footing do cidadão ao longo da Avenida Central não passava de um anticlímax, pois a verdade do Municipal não estava voltada para ela.

2 Os autocromos foram patenteados pelos Irmãos Lumière, na França, e começaram a ser comercializados em 1907. Apesar de produzirem apenas imagens únicas, foi o mais bem sucedido método de fotografia em cores até a Kodak lançar o seu processo, na década de 1930. 


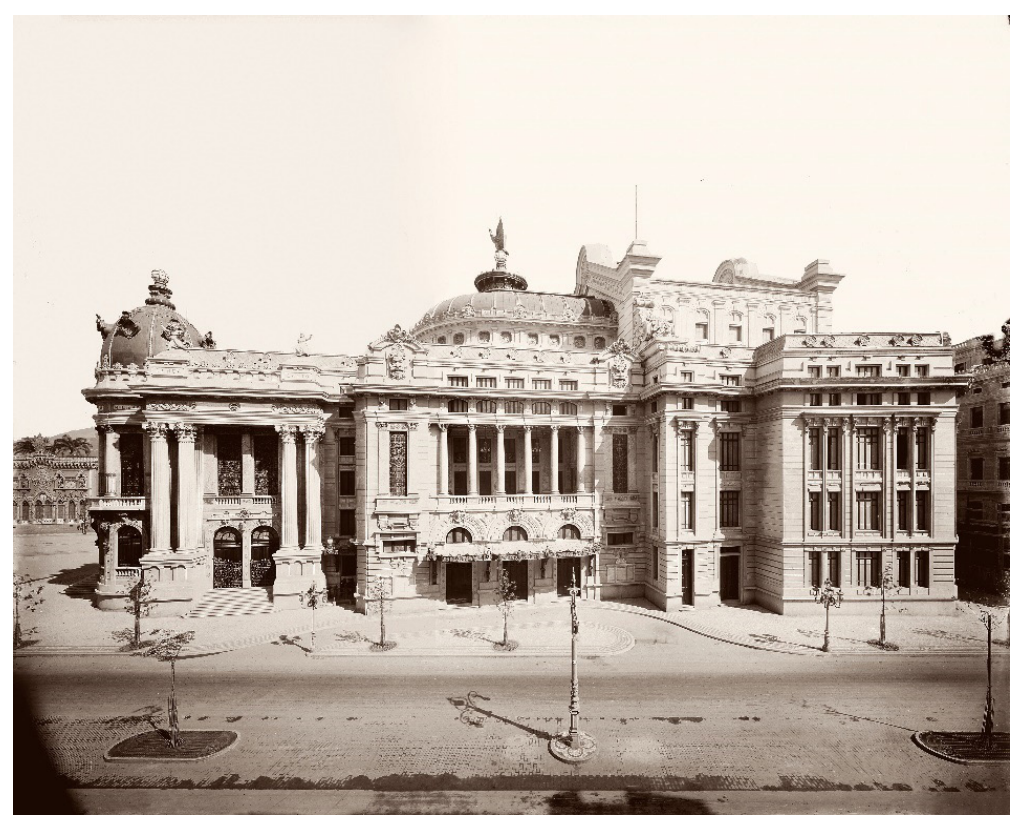

Fig. 3. Teatro Municipal do Rio de Janeiro (vista lateral), c. 1909.

Mas a visão desse desastre logo se dissipou diante de outra associação. Posicionado junto ao leito da nova via, o Municipal era uma locomotiva. A avenida, por sua vez, uma gigantesca plataforma parisiense onde estacionam os vagões-edifícios que representavam o progresso da capital, como uma composição ferroviária estendida por quilômetros. Talvez um corso, a sucessão carnavalesca de carros alegóricos - ou um cortejo fúnebre, monumentalizando as exéquias da cidade colonial.

As afinidades entre o trem e o primeiro cinema já foram bem estabelecidas: o cinema é uma fotografia que virou trem; o trem, uma janela que virou cinema; e o passageiro, um "protonarrador" (LASTRA, 1997, p. 284). Não se trata aqui de metáfora ou analogia, como os negócios cinematográficos de Ferrez comprovam. Em 1908, sua empresa fechou contrato com a Associação Geral de Auxílios Mútuos da Estrada de Ferro Central do Brasil, da qual decorreram as "fitas de estrada" que o público podia apreciar como paisagem em movimento (PRADILLA, 2019, p. 124). Nos seus primórdios, quando ainda não havia histórias para contar, assinala Victor Burgin (2006), a experiência do cinema integrava-se à flanerie urbana (p. 33). O progressivo afastamento dessa experiência original é marcada na linguagem cotidiana pela possibilidade de se dizer de alguém que finge, que simula, que está "fazendo fita". Mas, em 1907, quando Ferrez iniciava esses dois empreendimentos, o álbum da Avenida Central e o cinema Pathé, a distinção entre cinema e flanação mal começara a se fazer. 
Se os prédios da Avenida Central alinham-se como um corso de carros alegóricos, o álbum de Ferrez é outra coisa. É possível flanar de uma página a outra, mas seu padrão rigoroso, repetitivo, remete a uma coleção de tipos, uma galeria de "suspeitos", delinquentes ou criminosos contumazes. Afinal, como pergunta-se Walter Benjamin (1985) diante das fotos de Atget, não é todo "recanto" em nossas cidades o "local de um crime?" (p. 107) E que crime se esconde por trás das fachadas da Avenida Central? Logo nos recordamos: as demolições, o bota-abaixo, a expulsão dos moradores do centro antigo. O álbum da Avenida Central colhe na polícia das fachadas os retratos dos suspeitos acompanhados da devida antropometria, a reprodução de suas plantas.

"Polícia das fachadas" também não é uma metáfora. Muito se falou dela nas primeiras décadas do século XX. Sabemos que as licitações dos terrenos da Avenida Central exigiam a aprovação dos projetos. Zelava-se por seu valor artístico. Nas décadas seguintes, a prefeitura manteve comissões encarregadas de fiscalizar a aparência do que se erguia nas zonas nobres da cidade. Uma "polícia das fachadas" é expressamente reivindicada pelo jornal A Noite, por exemplo, quando dos debates em torno da urbanização da Esplanada do Castelo:

Se (apenas nas grandes cidades como S. Paulo e Rio) a terra não nos basta e precisamos escalar o espaço, façamo-lo com originalidade, aproveitando a inspiração de artistas nacionais, constituindo modelos próprios, estabelecendo a polícia das fachadas, de modo que o arbítrio e o mau-gosto individual não prejudique a harmonia de uma via pública. No Rio de Janeiro se devem levantar em breve novos quarteirões na larga esplanada do Castelo. Solicitamos daqui à Prefeitura Municipal que determine à comissão de engenheiros, já existente, o estudo dos tipos permitidos para a construção, de modo que, futuramente, não suceda com as novas ruas e praças, o que aconteceu em 1904, com a Avenida Central - a desordem de forma e colorido, que lamentável em nosso mostruário urbano de progresso e civilização (6/04/1926, p. 1).

Vinte anos depois de inaugurada, a Avenida Central, esse cortejo de maravilhas, havia se transformado, na percepção das elites cariocas, em um freak show arquitetônico. E o álbum-mostruário de Ferrez, em uma coleção de aberrações. Percorrendo agora suas páginas, finalmente compreendemos que o verdadeiro objetivo da polícia das fachadas nunca foi identificar os criminosos, mas ocultar o crime.

Há uma fotografia de Ferrez da Avenida Central, esquina com a Rua do Rosário. Do lado direito, os escritórios da companhia Guinle; do lado esquerdo, o Café Persa, também conhecido como Café Mourisco, projeto de Adolfo Morales de Los Rios, mestre do ecletismo carioca. Aqui, tudo se move. Os pedestres, as folhas que o vento balança, a charrete com dois cavalos. Tudo ligeiramente borrado, menos o maior de todos os símbolos da velocidade urbana, o automóvel, estacionado junto à calçada. Mover-se pela avenida, seguir os corsos ou os funerais - isso era o cinematográfico por excelência. 
Antes do cinema, esse percurso estendido não era exclusivo das janelas em movimento, pois era igualmente experimentado nos panoramas.

A evolução da técnica fotográfica no século XIX é tensionada por um paradoxo. Por um lado, persegue a velocidade, as emulsões rápidas, a ótica mais sensível, o controle cada vez mais acurado da obturação. Por outro, aspira o espetáculo, restituindo às imagens a temporalidade que o instantâneo lhes subtraía, procurando prolongar a visualização, dilatar a experiência do espectador. As duas formas mais bem sucedidas de retemporalizar a fotografia estão entre as técnicas mais apreciadas por Ferrez: os panoramas e a estereoscopia.

Quanto mais extensos os panoramas, mais difícil apreendê-los em um só golpe de vista. É preciso percorrer sua superfície. Em uma foto célebre da enseada de Botafogo, reitera-se a horizontalidade dos elementos - a praia, o mar sem ondas, o cais, o barco sem mastros ou velas, as edificações contornando a baía, a cadeia de montanhas no horizonte. Esses elementos superpõem-se como sedimentos e nos induzem a deslizar de um canto a outro da imagem, do marinheiro no barco grande ao cidadão que contempla a paisagem, sentado na praia. E de volta, na direção oposta, pois, para nossa surpresa, ele não olha na mesma direção que nós, mas mira algo que, a despeito da extensão do panorama, não podemos ver.

A inserção de um personagem no quadro é uma característica da paisagem fotográfica clássica. Nas décadas de 1840 e 1850, sua função primordial era familiarizar o espectador com a dimensão do que está sendo representado. Pouco a pouco, esses seres - nós os vemos com frequência nas paisagens de Ferrez - funcionam também como delegados do nosso olhar. Eles sublinham um dos valores fundamentais da boa paisagem oitocentista: a conquista do ponto de vista. Antes da emergência do pictorialismo e do instantâneo, a bela fotografia aposta todas as fichas no "enquadramento". Mesmo os valores composicionais, estritamente falando, estão subordinados ao movimento amplo de "seleção" do fotografável. A função do tripé, sublinhou Szarkowsky uma vez, "não era simplesmente manter a câmera em pé, mas preservar a decisão do fotógrafo feita antes que ele fechasse o obturador e a imagem do vidro do fundo desaparecesse" (SZARKOWSKY, 1989, p. 129).

As vistas fotográficas do século XIX são inseparáveis da noção de um percurso que as antecede e de um marco que nelas se inscreve (LISSOVSKY, 2014, p. 153). Em alguns panoramas de Ferrez, essa dupla função é exacerbada pela multiplicação de personagens desprovidos de vínculo entre si. A repetição da presença humana na paisagem é tão arbitrária que já não nos conta história alguma. Eu os vejo como homens-espeto que Ferrez finca no terreno como alguém que coloca pinos em um mapa. Mas isso também não é inteiramente desprovido de sentido, pois há algo de cartográfico nos panoramas. Eles favorecem o testemunho da lenta acumulação dos estratos. Mas o relevo também pode manifestar-se pelas poderosas forças telúricas que o transformam: "as brutais catástrofes que distorcem a face do mundo como uma careta" (LISSOVSKY, 2014, p. 166). A fotografia 
geológica de Timothy O'Sullivan estava especialmente interessada nas formações rochosas de origem vulcânica. A estereografia era o melhor dispositivo para dramatizar essas forças. Mas nem sempre o mero registro Ihe parecia suficiente. Algumas de suas imagens foram refotografadas, um século depois, por Rick Dingus. Descobrimos assim, por exemplo, como O'Sullivan valorizou seu ponto de vista por intermédio de um pequeno desvio de nove graus no horizonte, restabelecendo algo da força eruptiva das rochas em um vale de Utah (Witches Rock \# 5, 1869).

A despeito das grandes diferenças na conformação dos relevos brasileiro e norte-americano, não conheço investigações similares em torno da obra expedicionária de Marc Ferrez. Mas sua paixão pelos autocromos (e ainda pelo espetáculo, sem dúvida) o levaram a refazer algumas de suas vistas de maior sucesso. Em uma delas, observamos um movimento curioso: na estereoscopia do Pão de Açúcar, fotografado da Praia Vermelha, em 1912, o horizonte foi alterado pelo próprio Ferrez - e não corrigido como Dingus fez com O'Sullivan. Mas, ao contrário de tornar a rocha mais abrupta e disruptiva, a leve inclinação do novo Pão de Açúcar, símbolo da rotundidade das montanhas do Rio, torna o morro ainda mais orgânico, como um animal que acaba de assentar-se à beira d'água para descansar.

Tal como nos panoramas, as estereoscopias também nos convidam a um percurso no interior da imagem. Um percurso nada suave, pois não se restringe ao ótico. Ele desequilibra, surpreende, pois a profundidade nas estereoscopias não é um contínuo, mas um conjunto de planos sucessivos onde o percurso do olhar se faz em pequenos saltos. Na descrição precisa de Rosalind Krauss:

A imagem estereográfica parece ser multicamadas, um gradiente escarpado de planos diferentes afastando-se do primeiro plano em direção à profundidade... Enquanto nos movemos visualmente através do túnel estereoscópico, da inspeção de uma área próxima para um objeto situado à meia distância, tem-se a sensação de reenfocar os olhos... Estes esforços micromusculares são a contrapartida cinética da ilusão óptica da estereografia... O reajuste real dos olhos de um plano a outro no campo estereoscópico é a representação por uma parte do corpo do que outra parte do corpo (os pés) faria ao atravessar um espaço real (KRAUSS, 1996, p. 137-8).

O percurso no interior da imagem estereográfica é uma das mais fortes experiências de temporalização da fotografia no século XIX. No movimento imóvel que induz logo se percebeu um componente mágico, como observou Oliver Wendel Holmes, em 1861:

(...) o isolamento em relação aos objetos que nos cercam, e a concentração de toda a atenção, que é uma consequência disso, produz uma exaltação onírica das faculdades, um tipo de clarividência, na qual nós parecemos deixar o corpo para trás e navegar de uma cena estranha a outra, como espíritos desencarnados (HOLMES, 1872, p. 172). 
Marc Ferrez maneja a estereoscopia com maestria. Os volumes e pontos de interesse estão bem delimitados e espaçados, os planos próximos mais compactados entre si que os distantes - a composição de uma boa estereoscopia remete mais à escultura e ao diorama que à pintura. E há quase sempre um elemento a nos surpreender, entrando em quadro junto ao espectador. Essa terra dos sonhos para a qual a fotografia estereoscópica nos transporta - e da qual Walter Benjamin (1987) nos dá uma esplêndida descrição em "Kaiserpanorama" (p. 75-77) - terá no cinema sua mais plena realização. Pois a sala de cinema, o escurinho do cinema, oferece um refúgio ao citadino - não apenas para o burburinho das ruas, mas para o tédio, que vai tomando conta das massas urbanas em proporções avassaladoras. ${ }^{3}$ Mas o preço pago por elas para escapar do tédio era um certo torpor alucinógeno. Christian Metz escreveu uma vez: "Sair do cinema é um pouco como sair da cama: nem sempre é fácil" (METZ; GUZZETTI, 1976, p. 86).

Aos olhos de hoje, o que nos impressiona em uma vista diurna da Praça 15, no Rio de Janeiro (c. 1885), é como o lugar parece estar à espera dos carros que ainda virão. Nas grandes áreas abertas do Centro, as árvores mal começaram a crescer e os poucos transeuntes andam a pé. Uma paisagem humana tão rarefeita faz pensar em uma cidade habitada por sonâmbulos. Os cidadãos antecipam essas figuras de video game cujos movimentos estão predeterminados por algoritmos: afastadas uma das outras, ainda que trombem, nunca se encontram de verdade. O sonambulismo pode ter sido uma das características das novas populações urbanas capturadas, hipnotizadas pelo que mais tarde será chamado "sociedade do espetáculo'. Sonâmbulo era todo espectador de cinema, saindo da sessão.

No Largo de São Francisco, diante da antiga Escola Politécnica, onde estudaram os engenheiros que reformaram o Rio de Janeiro, estamos mais próximos dos habitantes (Figura 4). Fragmentos de narrativas espalham-se pelo quadro. Já choveu ou ainda vai chover? O jovem no centro da praça parece aliviado, pois o policial passou por ele sem nada desconfiar. E há essa senhora, que conversa animadamente com o padre enquanto caminham juntos para o lado de cá da praça, onde fica a Igreja. Que assunto terão? Há pouco humor nas fotografias de Ferrez, mas certamente notou a barraca de doces que anuncia em "falso inglês" American Kande, pois deu a ela posição de destaque na composição. A menina que o pai conduz pela mão vai perceber o doceiro? Fará pirraça porque não pode lambuzar o rosto ou sujar o vestido de passeio?

3 Nas Passagens, Benjamin anotou que "o tédio começou a ser experimentado em proporções epidêmicas durante os anos 1840" (BENJAMIN, 1999, p. 110). Nessa obra, as referências a uma onda de tédio que invade a Europa coincidem com o período da invenção e difusão da fotografia (LISSOVSKY, 2019, p. 7-8). 


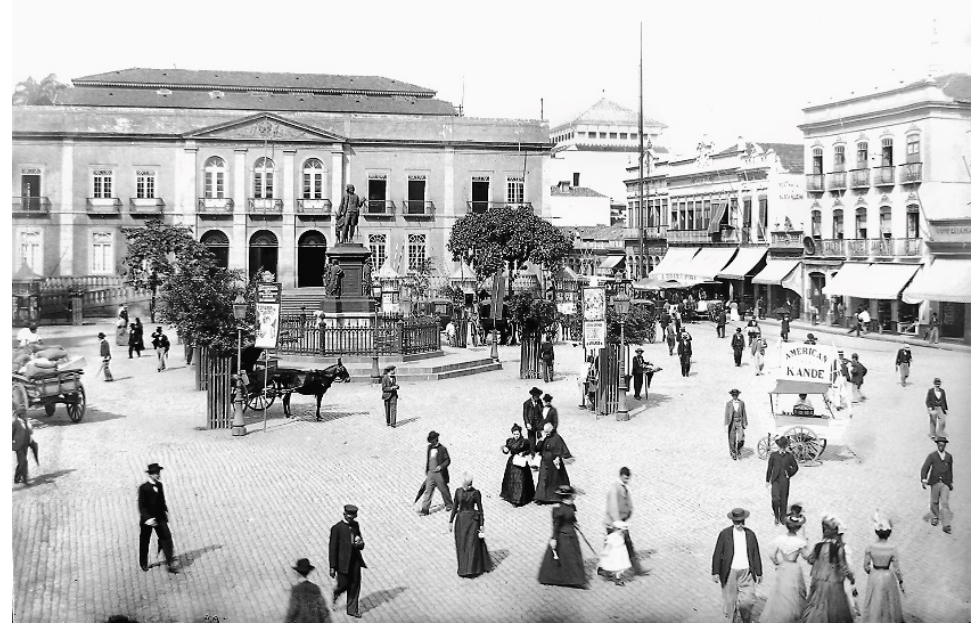

Fig. 4. Largo de São Francisco, Rio de Janeiro, c. 1890.

Talvez Ferrez desconfiasse já do americanismo do doceiro como viria a desconfiar, no tempo da Grande Guerra, da invasão do cinema norte-americano. Na sua opinião, Hollywood não agradaria tanto o público brasileiro quanto o cinema francês que sua companhia representava. Estava enganado a respeito das futuras inclinações da audiência, mas o cinema já havia se infiltrado em seu olhar. As estereografias que irá produzir a partir de 1912 aspiram ao fotograma. Não para perder-se na imagem, como acabei de fazer em minhas observações acerca da fotografia do Largo de São Francisco. Ferrez não pretende se deixar levar pelo que João do Rio chamava "labirinto dos fatos, da vida alheia e da fantasia", não quer ser "arrastado" como simples operador cinematográfico pela "torrente dos acontecimentos" (SUSSEKIND, 1987, p. 47). Não se trata mais de ser apenas um observador dos acontecimentos e da paisagem.

\section{No jardim dos autocromos}

Ferrez experimentou com os autocromos uma liberdade que não se permitia quando a fotografia era seu principal ganha-pão. Pradilla (2019) chama a atenção para uma correspondência de 1914 na qual, no contexto de uma guerra que promete ser longa e que perturba os negócios, imagina que, com o recebimento de placas coloridas, poderá se "ocupar de forma mais agradável" (p. 133). O entretenimento prossegue durante sua estadia na Suíça e na França, de 1915 a 1917, a ponto de lamentar a chegada do inverno, 
quando a luminosidade não seria suficiente para prosseguir fotografando em cores com método Lumière, que exigia grandes tempos de exposição (p. 136-139).

Nos autocromos europeus não estamos mais diante de poses, em sentido estrito, mas de "cenas" (Figura 5). A liberdade que lhe confere o fotograma diverte-o ainda mais que o colorido. Estamos longe do tipo de autonomia formal buscada pelo instantâneo fotográfico moderno. Pelo contrário, avizinha-se uma história da qual só dispomos de um fragmento... Ela veio por ali, por aquele caminho que mal se distingue da vegetação do campo. Senta-se longe de todos, não para descansar, mas porque algo a perturba. Ela não sorri, não olha para o fotógrafo, não faz pose para o espectador. Indiferença fingida de personagem de filme. Seu olhar se detém em algo distante. Não sabemos o que é. Parece não Ihe dar importância, - mas mesmo assim, aumenta sua tristeza.

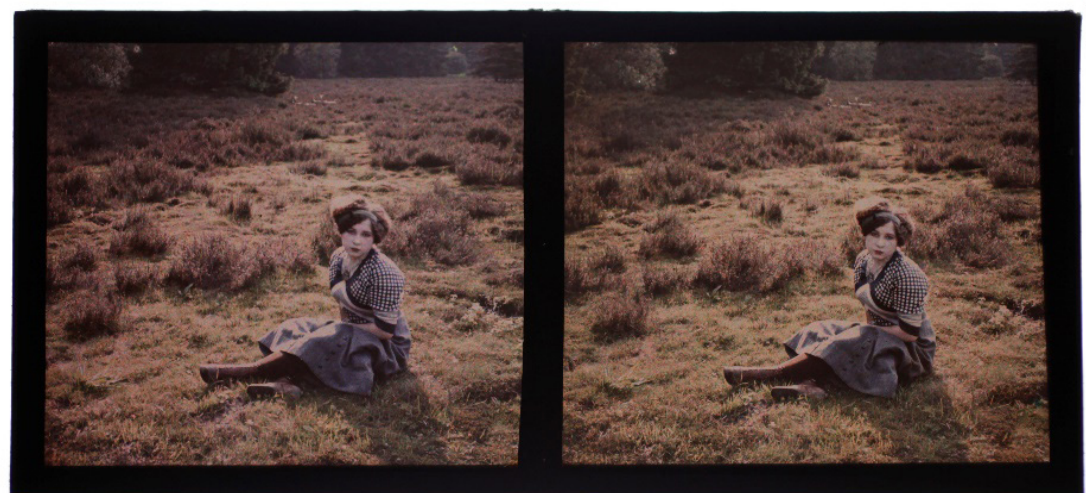

Fig. 5. França ou Suíça, entre 1915 e 1918.

Victor Burgin (2006) refere-se aos lugares de transição entre cinema e outras imagens - a fotografia em particular - como "heterotopias", tomando a expressão emprestada de Foucault. Para o filósofo francês, a heterotopia caracteriza-se pela justaposição em um espaço real de lugares, em princípio, incompatíveis. O grande barco do século XIX, por exemplo, como lugar sem lugar, cruzando o oceano - uma cidade flutuante (p. 10). Em minha opinião, a heterotopia fotográfica por excelência foi (e ainda é, se considerarmos os dispositivos imersivos da atualidade) a estereoscopia. Claro que o teatro "faz suceder sobre o retângulo do palco, toda uma série de lugares que são estranhos uns aos outros" e depois o cinema os faz desfilar numa tela. Ambos são, nesse sentido, heterotópicos. Mas Foucault nos diz que o exemplo mais antigo seria o jardim, "espantosa criação" milenar que tinha no Oriente uma significação mágica (FOUCAULT, 2013).

O jardim é o ambiente privilegiado dos autocromos europeus de Marc Ferrez. Neles, o percurso estereoscópico incorpora uma narrativa (Figura 6). Há quase sempre uma sugestão do caminho percorrido pelas personagens ou daquilo que faziam antes de ser 
fotografadas. Mas, principalmente, estão engajadas em uma ação. Nos termos que Michael Fried tomou das premissas de Diderot acerca da pintura e do teatro, a cena procura bastar-se a sim mesma, pois não reivindica o observador: a personagem está inteiramente absorta em seus afazeres (FRIED, 1988). A magia do jardim, no entanto, insinua-se. Foi o vermelho do lenço na cabeça que fez brotar as flores, como aquelas que bordaria no tecido branco? $\mathrm{Ou}$ a fotografia apenas revela que a moça suíça está inteiramente sob o domínio do canteiro?

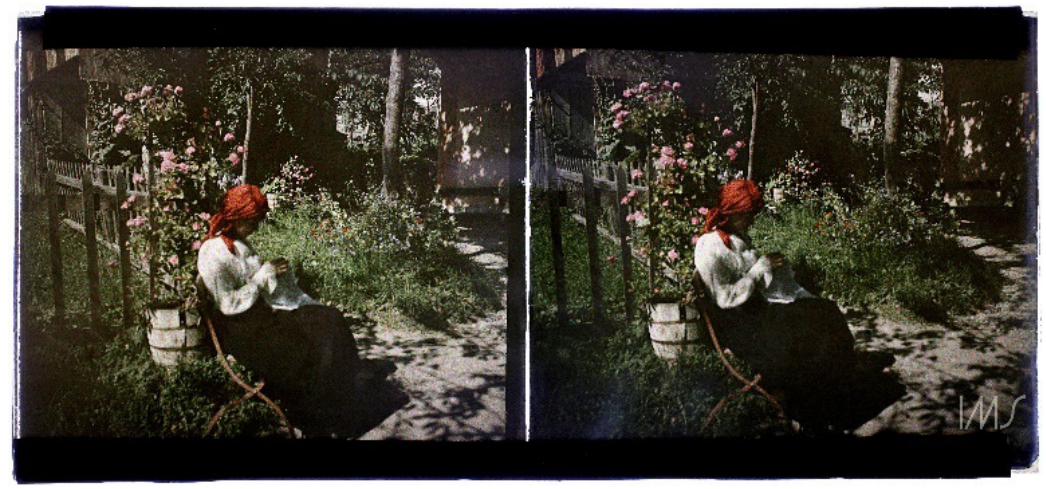

Fig. 6. Suíça, c. 1915.

A jovem estava tão absorta no bordado que não percebeu a presença do fotógrafo. Em outra cena de jardim, no entanto, ele é notado assim que se aproxima, e o personagem interrompe sua ação (Figura 7). Estaria escrevendo um soneto ou conferindo a contabilidade? O poema é mais provável, pois há uma evidente relação entre as flores e a caneta que acaba de sair do papel. Decidimos pelo soneto. Aqui também, como na estereografia do Pão de Açúcar que comentei anteriormente, o horizonte perdeu sua ortogonalidade. Mas o movimento é da própria câmera, que teria se apressado para surpreender o poeta em atividade.

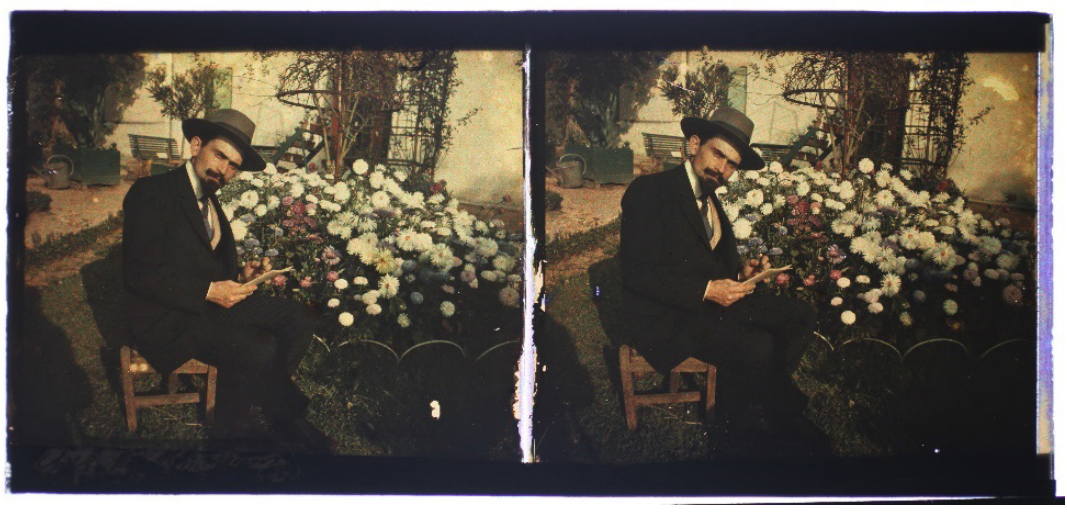

Fig. 7. Suíça, c. 1915. 
Agora o rapaz e a moça estão próximos um do outro (Figura 8). Ela é uma atriz de poucos recursos. Talvez pretenda mostrar-se demasiado tímida ou insensível ao galanteio. Será que não tem qualquer interesse no soneto que ele escreveu? Não devemos apostar na frieza ou indiferença da moça, pois as flores que emanam de seu lenço envolvem o rapaz. Mesmo assim, estando ele a ponto de tocá-la, permanece impávida. Será que ele está realmente ali ou já teria partido? Para a guerra, provavelmente. Teria morrido? Talvez ela o espere ou sonhe com ele enquanto borda. Uma Penélope dos Alpes à espera de seu Ulisses. A pequena auréola florida que paira sobre a cabeça dele enlaça-o, amorosamente.

A fenomenologia dos dispositivos do cinema e da estereoscopia guardam similaridade, observou Rosalind Krauss (1996): ambos envolvem isolamento do observador e a imagem é preservada de interferências externas: "em ambos a imagem transporta o espectador oticamente", enquanto seu corpo permanece imóvel (p. 139). Roland Barthes (2004), no escurinho do cinema, as pernas dobradas, os joelhos apoiados no encosto da poltrona da frente, escreve: "sou hipnotizado por uma distância; e essa distância não é crítica (intelectual); é, por assim dizer, uma distância amorosa" (p. 433). O velho fotógrafo, no ambiente imersivo dos autocromos, pode gozar do mesmo deleite do "discreto", para seguirmos com os termos de Barthes. Ele desfruta: "um prazer nas diferenças, nas distâncias", "um deleite tátil na heterogeneidade" (BURGIN, 2006, p. 44).

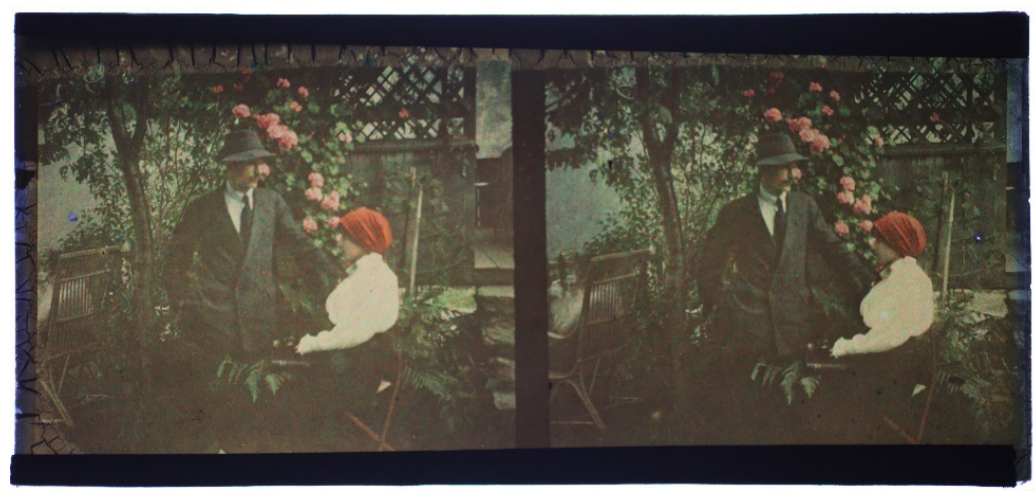

Fig. 8. Suíça, c. 1915.

Contrastando com as cenas claramente elaboradas, há um raro instantâneo entre os autocromos europeus de Ferrez (Figura 9). Mas instantâneo de quê, exatamente? Não se trata de velocidade ou movimento. A não ser pela ação do vento, o movimento como tal interessou pouco à fotografia de Ferrez. O instante aqui registra uma descoberta, a descoberta das correspondências: a mulher-árvore, a cabeça-copa. Sua irmã ou mãe está logo ali atrás, à direita. Mais provavelmente mãe, pois uma trilha umbilical conecta as duas personagens. Há uma anedota, há algo de risível nessa fotografia; mas, como em 
toda estereoscopia, há também assombração. Não há chiste sem uma rápida passagem pelo inconsciente, ensina Freud (1981): a deformação da cabeça é a primeira característica da monstruosidade. A mulher-monstra, a árvore andante, vem na minha direção.

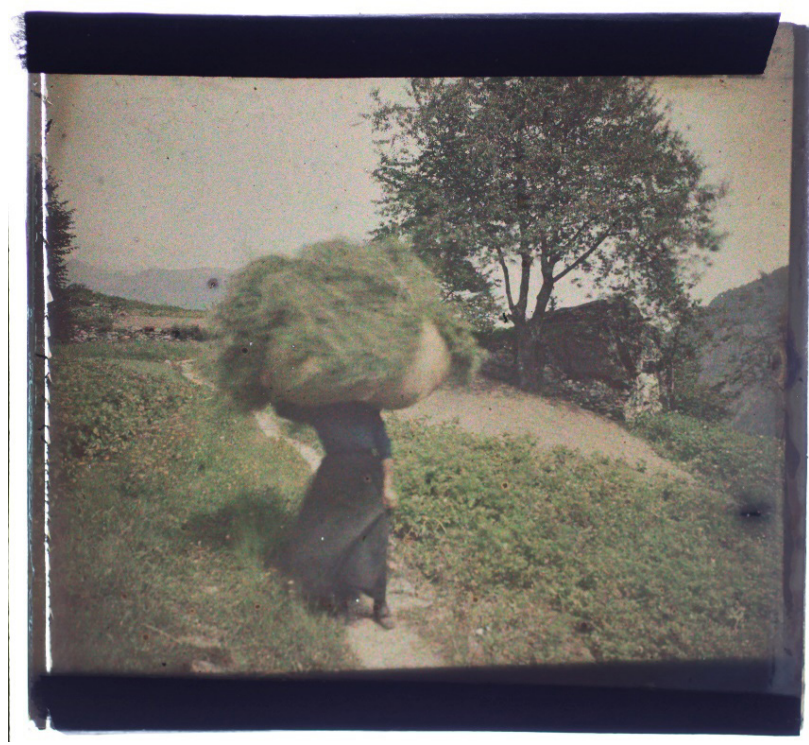

Fig. 9. França ou Suíça, entre 1915 e 1918.

Estamos, finalmente, no primeiro terraço dos jardins de Hyères, o mais antigo refúgio de inverno da Riviera francesa (Figura 10). Desde a Roma antiga, os médicos recomendavam a seus pacientes mais abastados uma estadia na cidade para fugir do frio. Um viajante inglês que a visitou em 1880, escreveu: "Não existe melhor prova das vantagens climáticas de Hyères que a vegetação que cresce ao ar livre, flores no inverno, sobrevivem incólumes aos dias mais frios do ano" (SMITH, 1880, p. 42). E ainda há palmeiras, como numa cidade tropical da África ou das Américas. A mulher se debruça sobre a murada, no caminho do velho castelo. Poderíamos dizer que ela contempla o Mediterrâneo, mais uma vez, como delegada do nosso olhar. Mas não é disso que se trata, pois não estamos muito interessados na vista. Sobre o banco à esquerda, um sobretudo e uma bengala. Acabou de repousar ali por alguns minutos, para recuperar-se do esforço da subida. E há esse homem velho. O que faz, afastado da murada? Talvez já tenha percorrido esse caminho antes e apenas recomendou o belvedere, assinalando esse ou aquele detalhe na paisagem. Trata-se ainda do fotógrafo oitocentista que determina e celebra o ponto de vista? Não creio, pois nesse, como em muitos autocromos europeus, a analogia entre mulheres e plantas persiste. Logo percebemos que, do vestido verde da personagem, brota um tufo vegetal. E as árvores, em uníssono, acompanham sua inclinação sobre a murada. O velho fotógrafo, com o olhar 
renovado, agora é o diretor de cena, o regente, o maestro que conduz a inclinação das árvores, cujos galhos, como violinistas de uma orquestra, sincronizam suas arcadas com o corpo feminino debruçado sobre o mar.

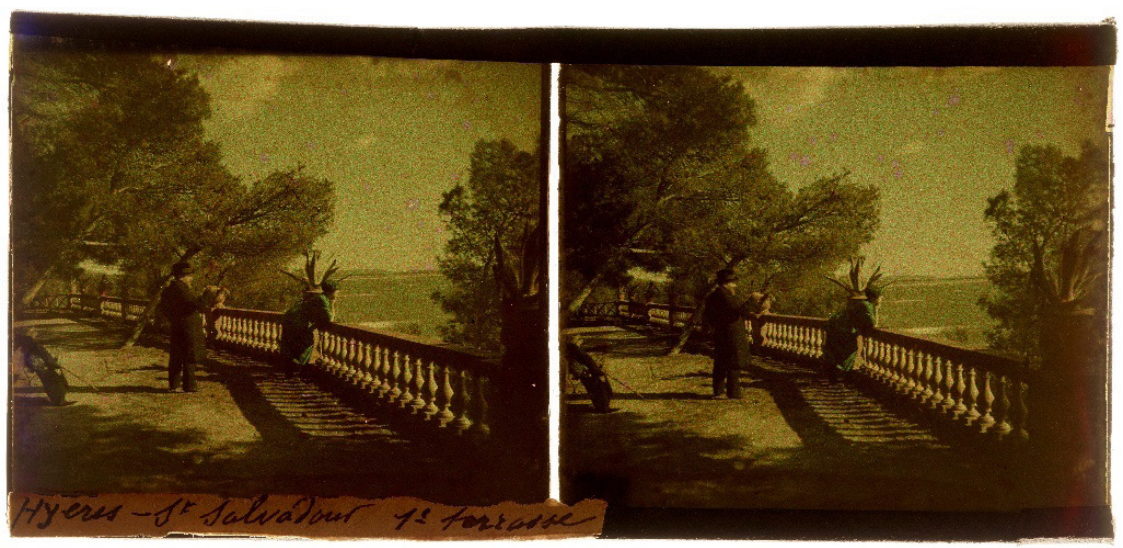

Fig. 10. Hyères, França, 1921.

\section{Conclusão}

Infiltrada pelo fotograma, a estereoscopia de Ferrez deixa de ser apenas o território que um espectador trôpego visita maravilhado. Diante da avassaladora profusão das imagens técnicas planas da guerra que os periódicos imprimem, ela muda de sinal e se torna o refúgio de uma interioridade que reencontra no jardim a magia da imagem técnica. Apesar de identificadas e localizadas (Bordeaux, Vichy, Suíça, Hyères...) não são souvenires de terras estrangeiras, são imagens-resíduos, entre o sonho e a recordação, cuja localização geográfica pouco importa. Evocam fotogramas, mas não foram extraídas de algum filme, pois, habitando o estranho mundo do dispositivo estereoscópico, subsistem em algum lugar situado entre a realidade externa, que toca a todos, e os devaneios mais íntimos de cada um.

Como tecnologia imersiva, a fotografia estereoscópica não acontece apenas diante dos olhos, mas cria um espaço imaginário no interior de nosso próprio crânio, uma caverna onde a luz penetra por dois orifícios. A estereoscopia deixa de ser apenas o percurso heterotópico no interior da imagem, uma vez que agora habita a minha cabeça. Ela nos sugere uma história, torna-se um lugar onde o corpo poderia viver livre de si mesmo, sem o peso dos anos, sem dores ou enfermidades - espaço tridimensional onde, paradoxalmente, não há volume. Libertos do corpo, somos transportados a esse espaço utópico pelo tapete mágico de um jardim voador.

O cinema, talvez Ferrez já tivesse se dado conta, selecionando semanalmente os filmes da Pathé que iria exibir no Brasil, é o esgotamento da novidade, o último e 
mesmo espetáculo repetido à exaustão. As fotografias amadoras que realiza na Europa são radicalmente diferentes de suas imagens anteriores porque nascem agora do tédio e da lassidão. "Vai-se ao cinema", anotou Barthes (2004, p. 428), "a partir de uma ociosidade, de uma disponibilidade, de uma vacância". Enquanto a guerra não passa, enquanto a cura não vem, não são mero passatempo, mas ócio amoroso. Estamos, nas estereoscopias de Ferrez, no limiar da fotografia moderna, tal como ela emergirá da catástrofe cubista da Grande Guerra. Uma nova Fotografia que não será mais o trem que chega à estação, mas a passageira que espera na plataforma.

(Escrito durante a pandemia da Covid-19, março-abril/2020)

Mauricio Lissovsky é professor da ECO-UFRJ e pesquisador do CNPq.

mauricio.lissovsky@eco.ufrj.br

\section{Referências}

BARTHES, R. Ao sair do Cinema. In: O rumor da língua. São Paulo: Martins Fontes, 2004. p. 427-433. BENJAMIN, W. Pequena história da fotografia. In: Obras escolhidas I (Magia e técnica, arte e política). São Paulo: Brasiliense, 1985. p. 91-107.

BENJAMIN, Walter. Infância em Berlim por volta de 1900. In: Obras escolhidas II (Rua de mão única). São Paulo: Brasiliense, 1987. p. 71-142.

BURGIN, V. The remembered film. Londres: Reaktion Books, 2006.

FOUCAULT, M. De espaços outros. In: Estudos Avançados, v.27, n.79, 2013.

FREUD, Sigmund. El chiste y su relación con el inconsciente (1905). In: Obras completas I (18731905). Madrid: Biblioteca Nueva, 1981.

FRIED, M. Absortion and theatricality: painting and beholder in the age of Diderot. Chicago: University of Chicago Press, 1988.

HOLMES, O. W. Sun-painting and sun-sculpture. In: Soundings from The Atlantic. Boston: James R. Osgood and Company, 1872. p. 166-227.

KRAUSS, R. The Originality of the Avant-garde and other modernist myths. Cambridge: MIT Press, 1996.

LASTRA, J. From the captured moment to the cinematic image: a transformation in the pictorial order. In: ANDREW, Dudley. The Image in Dispute; art and cinema in the age of photography. Austin: University of Texas Press, 1997. p. 263-291.

LISSOVSKY, M. Pausas do destino: teoria, arte e história da fotografia. Rio de Janeiro, Mauad X, 2014. LISSOVSKY, M. "The Tourist and 'The One Who Waits'; the double time of modern photography". Anthropology \& Materialism, n. 4, 2019, p. 1-16. https://doi.org/10.4000/am.1019 
METZ, C.; GUZZETTI, A. The fiction film and its spectator: a metapsychological study. In: New Literary History (8), n. 1, 1976, p. 75-105.

PRADILLA CERÓN, I. Marc Ferrez, uma cronologia da vida e da obra. São Paulo: IMS, 2019.

SMITH, A. The garden of Hyères: a description of the most southern point on the French Riviera. Londres: J. Evans, 1880.

SUSSEKIND, F. Cinematógrafo de letras. São Paulo: Companhia das Letras, 1987.

SZARKOWSKY, J. Photography until now. Nova York: MoMA, 1989.

Artigo recebido em 03/04/2020

e aprovado em 25/04/2020. 